\title{
ON THE RELATIONSHIP BETWEEN RTA EXPANSION AND \\ OPENNESS
}

\section{Michele Fratianni* and Chang Hoon Oh**}

\begin{abstract}
$\underline{\text { Abstract }}$
We test the relationship between the size of regional trade agreements (RTA) and openness using a gravity equation with multilateral trade factors on a large sample of 143 countries over period 1980-2003. Our sample includes eleven RTAs, seven with constant membership and four with an expanding membership. In the first group, there are more stumbling blocs than building blocs to freer global trade. In the second group, the opposite holds. We also find that regional trade bias declines with the size of the club and that three of the four expanding RTAs have already surpassed their 'optimal' size.
\end{abstract}

Key Words: gravity equation, plurilateral RTAs, size, trade creation, trade diversion

JEL Classification: F13

* Indiana University, Kelley School of Business, Bloomington, IN 47405 (USA) and Università Politecnica delle Marche, Department of Economics, Ancona (Italy), Ph. 1-812-855-92919, Fax 1-812-855-3354, Email fratiann@indiana.edu. ** Indiana University, Kelley School of Business, Bloomington, IN 47405 (USA), Ph. 1-812-855-92919, Fax 1-812-855-3354, Email

chaoh@indiana.edu. We thank an anonymous referee of the Department of Economics in Ancona for comments on an earlier and shorter version of this paper. 


\section{Introduction}

Regional trade agreements (RTAs) have been a prominent feature of the world economy since the creation of the European Economic Community in the late 1950s. Two aspects of this feature are worth noting. The first is the rapid growth and complexities of these arrangements (Crawford and Fiorentino 2005), although quite a few of them are bilateral agreements of small consequence for international trade (Pomfret 2006, p. 42). The second is that several plurilateral RTAs have expanded in size and economic importance. The European Union (EU) has grown from the original six members of 1958 to the current (2007) size of 27; and further enlargements are in the making. The economic size of the EU is comparable to that of the United States. The Association of South East Asian Nations (ASEAN) has gone through a few expansion phases; as of 2006 it had 10 members and one candidate, East Timor, waiting to join. The economic size of ASEAN is approximately 15 per cent of that of the EU. The North American Free Trade Association (NAFTA) has enlarged once, in 1994 with the addition of Mexico to Canada and the United States. The Southern Common Market (MERCOSUR) has also enlarged once, in 2006 with the addition of Venezuela to the original four members; it has five associate members and one observer.

The RTA phenomenon has sparked a growing literature on the role of RTAs in the international trade system; see review article by Panagariya (2000). Our paper intends to address empirically the relationship between RTA size and trade bias, and is motivated by an old question and a new question. The old question is whether RTAs are "building" or "stumbling" blocs, where "building" means that RTAs expand world trade and "stumbling" the opposite. ${ }^{1}$ A pure building bloc occurs when RTA members trade with one another in excess of the trade

\footnotetext{
${ }^{1}$ The terminology of building and stumbling blocs was first introduced by Bhagwati (1991). For relevant literature on this topic, see Section 7 in Panagariya (2000).
} 
flows implied by a reference model and without any reduction of trade flows between members and non-members, again beyond the trade flows implied by a reference model. This corresponds to the case of trade creation (TC) without trade diversion (TD) in Viner's (1950) classic study of customs unions. If TD occurs, the RTA expands world trade only if TC exceeds TD; we may call it a weak building bloc. If TD fully offsets TC, the RTA fully reallocates trade from outsiders to insiders; we may call it a weak stumbling bloc. If TD more than fully offsets TC, the RTA is a pure stumbling bloc.

The new question deals with RTA expansion. Larger internal markets resulting from expanding RTAs may make it easier to implement beyond-the-border liberalization programs, as the EU did it in the 1980s with its internal market initiative. Trade creation rises, but trade diversion may rise as well. Since larger RTAs tend to have a higher ratio of internal trade to GDP than smaller RTAs, the pressure to liberalize trade with non-members may decline. Not surprisingly, the EU and the United States protect sensitive sectors like agriculture and textiles where developing countries have a comparative advantage. ${ }^{2}$ In the end, whether an expanding RTA tends to be more of a building than a stumbling bloc is an empirical issue.

Our research strategy is as follows. We first estimate the size of the regional trade bias (or TC) and trade diversion for each of eleven RTAs relative to a reference model. The reference model is the gravity equation (GE) of bilateral trade flows developed by Anderson and van Wincoop (2003, AvW for short) and our sample period cover 24 years, 1980 through 2003. A critical feature of this GE is that trade flows, not only reflect the forces of bilateral trade barriers, but also the barriers imposed by all other countries on a given country pair. Older GEs that ignore multilateral trade factors are fraught with an omitted variable problem and do not yield consistent and efficient estimates of TC and TD; consequently, the empirical findings based on

\footnotetext{
${ }^{2}$ Many political economy models of RTAs emphasize trade diversion; see Panagariya (2000).
} 
these older GEs have to be taken with a grain of salt (Carrère 2006). We will also estimate TC and TD effects for the different sizes of four RTAs that have enlarged over the sample period. These estimates allow us to infer whether size increases have gone more in the direction of enhancing than erecting obstacles to world trade growth.

This paper is organized as follows. In Section 2 we review the theoretical and empirical literature on the relationship between the size of RTAs, trade creation and trade diversion. In Section 3 we present the gravity equation with multilateral trade factors and the main econometric issues underlying the testing of this equation. The empirical findings are presented and discussed in Section 4. We end with conclusions.

\section{Size of RTAs, Trade Creation and Trade Diversion}

In this section we review the essential theoretical literature that bear on our topic of the relationship between RTA size and global trade, as well as some of the empirical literature on the TC and TD effects due to RTAs.

Krugman (1991) examines the trade effects of an expansion in the size of trading blocs. His point of departure is an exogenous number of RTAs of equal size, which set tariffs noncooperatively. An increase in the size of the blocs produces a classic combination of TC and TD. The enlarging RTAs divert trade partly because some of the trade between blocs occurs now within the blocs and partly because these charge a higher external tariff. Welfare level is described by a U-shaped function in the number of RTAs. A single RTA in the world does best because it promotes global free trade; many RTAs do well because they have small power and levy low tariffs; and an intermediate number of RTAs produces the worst outcome. TD need not occur if instead tariffs are set cooperatively. Bond and Syropoulos (1996) relax Krugman's 
assumption of symmetric blocs and obtain that a bloc has incentive to enlarge because by expanding it can increase welfare for its members above the free trade level. A more ambiguous case for RTAs comes out from Yi's (1996) model of endogenous customs union under imperfect competition. With symmetric countries, welfare improves for member countries but declines for non-member countries. Customs unions can perform as building blocs (towards global free trade) under open regionalism, where any country that applies to an RTA is accepted, but can become stumbling blocs when the decision to enlarge requires unanimity.

Andriamananjara (1999) develops a model of endogenous RTAs from a setting in which each national market has a single firm and is perfectly segmented, yet all firms produce perfectly substitutable goods. RTAs expand because firms make higher profits in a larger RTA than in a smaller RTA; clearly, insiders must allow the expansion. A bigger club has two effects. The first is the noted positive effect on profits due to a larger market with preferential treatment. The profit effect, however, declines as the RTA enlarges because the oligopoly power of each firm declines with RTA size. The second effect is that the formation of an RTA reduces the profits of the outsiders, which have an incentive to join the RTA. The optimal size of the club is not the world because insiders have an interest in restraining membership.

On the empirical side, Frankel, Stein, and Wei (1996) estimate a bilateral trade GE for 63 countries for the period 1965-1992 and find positive and statistically significant regional trade biases and a mixture of TC and TD effects. Soloaga and Winters (2001) estimate a GE for 58 countries for the period 1980-1996, separating import from export TD effects. Unlike Frankel et al. (1996), they do not find statistically significant regional trade biases, but uncover import and export TD for the EU and EFTA. Latin American RTAs, on the other hand, expanded total imports. Bayoumi and Eichengreen (1997) detect TD effects in the EU: the annual growth of 
trade between member countries and industrial non-member countries fell by 1.7 percentage points over 1956-1973. Crawford and Laird (2001) analyze trade data from six RTAs and find that for the period 1990-1999 the average annual growth of imports from non-members is slightly smaller than the average annual growth of insiders' imports.

It is worth repeating that empirical work based on old GEs -those that ignore multilateral trade factors- may be unreliable. Carrère (2006), after correcting for possible econometric misspecifications of the GE (which will be discussed in the next section), finds that her sample of seven RTAs generates a mixture of TC and TD effects. In particular, regional trade biases, over the period 1962 to 1996, were increasing through the expansion phases of the EU, MERCOSUR and NAFTA, accompanied often by a decline of imports from and exports to outsiders.

\section{The Gravity Equation and Econometric Issues}

It is now accepted that bilateral trade flows are best explained by the GE; see, among others, Bergstrand (1985, p. 474), Leamer and Levinsohn (1995, p. 1384), and Deardorff (1998, p. 7), and Feenstra, Markusen, and Rose. (2001, p. 431). The GE has been derived from different models of international trade, ranging from models of complete specialization and identical consumers' preferences (Anderson 1979; Bergstrand 1985; Deardorff 1998) to models of product differentiation in a regime of monopolistic competition (Helpman 1987) to hybrid models of different factor proportions and product differentiation (Bergstrand 1989) to models of incomplete specialization and trading costs (Haveman and Hummels 2004). For this paper, we rely on the formulation by AvW. 
In the AvW setting, countries enjoy complete specialization and consumers have homothetic preferences. Country i produces good $i$ at price $p_{i}$. In country $j$, the good is sold at price $p_{i j}=p_{i}\left(1+t_{i j}\right)$, where $t_{i j}$ imbeds a host of trade costs including transport and transaction costs, regime costs arising from differences in legal systems and practices, languages, networks, competitive policies, and monetary regimes, and tariffs or tariff-equivalent restrictions aimed at discriminating against foreign producers. These costs are, for the most part, non-observable and are proxied by physical distance, cultural distance and institutional distance. Thus, countries that are geographically distant face a higher $\mathrm{t}_{\mathrm{ij}}$ than contiguous pairs; countries that speak the same language and have common roots also face a lower $\mathrm{t}_{\mathrm{ij}}$ than pairs with heterogeneous cultural background; countries that share the same currency and the same central bank face a lower $t_{i j}$ than nations with different currencies and central banks; and finally countries that belong to the same RTA face lower $t_{i j}$ than countries that do not. Bilateral trade flows are determined as follows (see AvW, eq. 9):

$$
\mathrm{x}_{\mathrm{ij}}=\mathrm{y}_{\mathrm{i}} \mathrm{y}_{\mathrm{j}} / \mathrm{y}_{\mathrm{w}}\left(\mathrm{t}_{\mathrm{ij}} / \mathrm{P}_{\mathrm{i}} \mathrm{P}_{\mathrm{j}}\right)^{1-\sigma}
$$

where $x_{i j}=$ exports from country $i$ to country $j, y=$ income, the subscript $w=$ world, $\sigma=$ the elasticity of substitution coefficient, $P=$ the consumer price level. $P_{i}$ and $P_{j}$ stand for the multilateral trade costs in the AvW model and are a function of all $t_{i j}$ pairs, countries' income shares and countries' price levels. For $\sigma>1$, bilateral trade flows rise (fall) if multilateral trade costs rise (fall) relative to bilateral trade costs. $\mathrm{P}_{\mathrm{i}}$ and $\mathrm{P}_{\mathrm{j}}$ are jointly determined and their omission creates a bias in the estimated coefficients.

The testable equation of (1) is: 


$$
\begin{aligned}
\ln \left(\mathrm{x}_{\mathrm{ijt}}\right)= & \alpha_{0}+\alpha_{1} \ln \left(\mathrm{y}_{\mathrm{i}} \mathrm{y}_{\mathrm{j}}\right)_{\mathrm{t}}+\alpha_{2} \ln \left(\mathrm{I}_{\mathrm{i}} \mathrm{I}_{\mathrm{j}}\right)_{\mathrm{t}}+\alpha_{3} \ln \left(\mathrm{d}_{\mathrm{ij}}\right)+\alpha_{4} \mathrm{CC}_{\mathrm{ijt}}+\alpha_{5} \ln \mathrm{P}_{\mathrm{i}}+\alpha_{6} \ln \mathrm{P}_{\mathrm{j}}+ \\
& \beta_{1} \text { Same-RTA }_{\mathrm{ijt}}+\beta_{2} \operatorname{Im}_{\mathrm{Im}} \mathrm{RTA}_{\mathrm{ijt}}+\beta_{3} \mathrm{Ex}-\mathrm{RTA}_{\mathrm{ijt}}+\alpha_{\mathrm{t}}+\mathrm{u}_{\mathrm{ijt}} .
\end{aligned}
$$

The new terms are as follows. I is per capita income; $\mathrm{d}$ is distance; $\mathrm{CC}$ is a vector of dummy variables that capture various types of cost reducing affinity shared by the pair of countries such as common border, common language, common colonizer, common relationship and common currency - ; the three RTA variables capture TC and TD effects generated by the RTA and are discussed fully below; $\alpha_{\mathrm{t}}$ is a time effect common to all country pairs; and $\mathrm{u}_{\mathrm{ijt}}=\mu_{\mathrm{ij}}+\varepsilon_{\mathrm{ijt}}$, where $\mu_{\mathrm{ij}}$ is either a fixed or random unobserved bilateral effect and $\varepsilon_{\mathrm{ijt}}$ is the residual error term. It should be noted that (2) descends directly from (1). The per capita income emerges from (1) through the countries' income shares that influence the two price levels; these income shares are proxied by population.

\section{$\underline{\text { TC and TD effects and RTA size }}$}

In the GE literature, TC and TD effects generated by RTAs have been typically modeled by two dummy variables: Same-RTA, which is equal to one when both countries in the pair belong to the same RTA and zero otherwise, and Im-RTA, which is equal to one when the import country belongs to the RTA and the export country does not and zero otherwise; for more details, see Soloaga and Winters (2001). Pure TC is implied by $\beta_{1}>0$ and $\beta_{2}=0$. An expanding RTA that has those empirical characteristics can be said to have moved in the direction of an optimal size and to have raised welfare. If $\beta_{2}$ is negative, TD emerges and the case for RTA depends on the relative numerical size of the positive $\beta_{1}$ and negative $\beta_{2}$. An expanding RTA moves weakly in the "good" direction, towards an optimal size, if the positive $\beta_{1}$ is numerical larger than the 
negative $\beta_{2}$. Pure TD occurs when $\beta_{2}$ is equal to $\beta_{1}$; the expanding RTA, in this case, has moved in the "wrong" direction.

Soloaga and Winters (2001) point out that this two-dummy approach ignores the effect of the RTA on non-members' exports and the possibility that RTA members can gain at the expense of non-members. These authors propose third dummy, Ex-RTA, which is equal to one when the export country belongs to the RTA and the import country does not, and zero otherwise. With a three-dummy approach, the assessment of whether an expanding RTA is moving in the right or wrong direction depends not only on the relative numerical size of $\beta_{1}$ and $\beta_{2}$ but also of $\beta_{1}$ and $\beta_{3}$. Carrère (2006) adopts the Soloaga-Winters three-dummy approach.

The biggest challenge in estimating (2) is to make sure that one captures the multilateral trade factors; otherwise, the error term of the regression will imbed the effects of the variables that determine the two sets of prices and will create a bias in the other coefficients of the regression. AvW (pp. 179-180) solve the problem by estimating with nonlinear least squares a simultaneous system of equations for cross-section data. Rose and van Wincoop (2001) and Feenstra (2003) propose the use of country fixed effects, but this alternative is only applicable to cross-section data. Baldwin and Taglioni (2006) discuss pitfalls of panel estimation in the presence of multilateral trade factors. These authors dismiss the use of country fixed effects because they fail to take into account that $P_{i}$ and $P_{j}$ vary over time. They recommend instead country-pair fixed effects, as well as separate time fixed effects, to capture all pairwise idiosyncratic characteristics. Carrère (p. 231) accepts that country-pair fixed effects yield unbiased estimates of time-varying variables, but this model has the drawback of eliminating time-invariant variables. The alternative of estimating country-pair effects as random variables has greater economic appeal. 
We will estimate equation (2) under the two alternatives of fixed and random countrypair effects, in addition to fixed year effects. We will compare the two models and test the null hypothesis that the fixed effects model is not better than the random effects model. If the null cannot be rejected, we will then use the random model to infer TC and TD effects of RTAs.

\section{Data}

We briefly discuss our data here and invite the interested reader to check the Indiana University CIBER Website (http://www.kelley.iu.edu/ciber/research.cfm) and Appendix 1 for more details.

Our data set consists of 215,500 annual observations covering 143 countries over the period 1980 to 2003: see Appendix 2 for the list of 143 countries. Country-level bilateral imports in U.S. dollars come from the World Trade Analyzer (WTA) by Statistics Canada.. The remainder of the data, with the exception of currency unions and RTAs, come from Rose (2005) for the period 1980-1999 and our own update using the same sources as Rose's for the years 2000 through 2003. On RTAs, we identify eleven separate agreements that account for 40 percent of world trade: ASEAN, CARICOM (Caribbean Community and Common Market), EU, NAFTA, ANDEAN (Andean Community of Nations), CACM (Central American Common Market), MERCOSUR, PATCRA (Papua New Guinea-Australia Trade and Commercial Relations Agreement), ANZCERTA (the Australia-New Zealand Closer Economic Relations Trade Agreement), SPARTECA (South Pacific Region Trade and Economic Cooperation Agreement), and USIS (the United States-Israel Free Trade Agreement). The first four of the eleven RTAs have expanded since 1980. Details of the formation and enlargements of the eleven RTAs are shown in Appendix 3. 
The mean value of bilateral imports is 341 million US dollars, with a range spanning from one thousand to 201 billion dollars. The mean value of GDP is 286 billion dollars, with a range spanning from 21 million to 11 trillion dollars. The mean value of per capita GDP for importing countries is 6,000 dollars, with a range spanning from 83,000 to 48,000 dollars. The average value of distance is 4,589 miles, with a range spanning from 55 to 12,351 miles.

Country-pair observations with a common land border represent 2.7 per cent of the sample; those with a shared language 21.4 per cent; those with a common colonizer 8 per cent; those with a shared colonial relationship 2.3 per cent; those with a common currency 0.9 per cent; and those belonging to the same RTA 2.6 per cent. Table 1 shows descriptive statistics for the three RTA dummy variables for the 11 separate agreements. Sample averages for these dummies tend to be relatively low for ASEAN7 (read ASEAN with 7 members), CARCOM 11, NAFTA2, and EU9, and relatively high for SPARTECA, EU12 and E15, with the averages reflecting the size and time length of RTA.

[Insert Table 1 here]

\section{Empirical Findings}

Estimates of (2), with both fixed and random country-pair effects and fixed year effects, are reported in Table 2. The $\mathrm{R}$ squares are high by the standards of the GE equations estimated in the literature but are comparable to those reported by Carrère (2006, Table 2). Most coefficients, with the exception of those involving RTA dummies, are statistically significant at the 1 per cent level. In the fixed effects model, the impact of income on bilateral imports is in line with prediction, but the impact of per capita income is not. Time-invariant dummy variables are made redundant by the estimation of the fixed effects model. The alternative of random country-pair 
effects passes the Breusch and Pagan (1980) LM test and the Hausman (1978) test that the fixed effects model is not better than the random effects model. Therefore, we will concentrate on the random effects model for the remainder of our discussion.

The estimated $\alpha$ s of the random effects model of equation (2) appear to be in line with those reported in the literature. The per capita income variable has the predicted sign, in contrast to the fixed model. The size of the elasticity of bilateral imports with respect to income is less than one; the elasticity with respect to distance is numerically larger than one and confirms to be a powerful force in the gravity equation; geographical proximity and cultural affinity variables enhance trade. Countries that share a common currency do not trade any more than those that have different currencies (the coefficient of common currency is not different from zero at the 10 per cent significance level). This result may be surprising given that Rose (2000) has reported that countries with a common currency trade three times as much as countries with different currencies (and fluctuating exchange rates). However, Rose's (2000) finding has been met with skepticism from the start; see the comments to Rose by Persson (2001). From the viewpoint of this paper, the serious problem with Rose's GE equation is the omission of multilateral trade factors. Baldwin and Taglioni (2006) focus on Rose's finding to demonstrate the distortion that such an omission can create. To check on this point, when we estimated (2) with fixed importing-country (instead of fixed country-pair effects) and year effects, the coefficient of common currency turned out to be 0.62 and statistically significant at the 1 per cent level. ${ }^{3}$

[Insert Table 2 here]

\footnotetext{
${ }^{3}$ Regression results are not shown but are available upon request. Similar findings are reported by Barldwin and Taglioni (2006).
} 


\section{$\underline{\text { Non-expanding RTAs }}$}

Having disposed of the general characteristics of the estimated GE, we can now concentrate on the impact of RTAs on bilateral trade flows. We recall that our sample includes 11 RTAs, of which four have expanded at least once since 1980. We consider first the non-expanding RTAs. SPARTECA is the pristine example of a pure building bloc towards global free trade, with a strong regional trade bias accompanied by expansion of imports and exports to the rest of the world. ANDEAN as well is a building bloc, although weaker than SPARTECA: it has a sizeable regional trade bias and a small import TD. ${ }^{4}$ USIS has a positive regional trade bias but also a fully offsetting import TD; there is also some evidence of export TD. ${ }^{5}$ Therefore, USIS is a pure TD case and an obstacle to global free trade. The remaining four non-expanding RTAs ANZCERTA, CACM, MERCOSUR, and PATCRA-- show evidence of TD, either on the import or the export side, and no evidence of positive regional trade bias; they too must be classified as stumbling blocs. In sum, of the seven non-expanding RTAs covered by our sample, only two have behaved as building blocs.

\section{Expanding RTAs}

Of the remaining four RTAs, ASEAN, CARICOM and the EU have expanded three times during our sample period and NAFTA only once. ASEAN is the perfect example of an expanding building bloc. In each successive enlargements, a strong and statistically very significant positive regional trade bias has been matched by an equally strong expansion of imports and exports to the rest of the world. Judged exclusively in terms of the size of the regional trade bias, ASEAN seems to have peaked with a membership of nine; see Table 3.

\footnotetext{
4 The export TD effect is not statistically significant at the 10 per cent.

5 The export TD effect is significant at the 10 per cent.
} 
The EU can also be considered a building bloc, although weaker than ASEAN. EU9 has a marginally significant positive regional trade bias and expanding imports and exports to the rest of the world. EU10 is not statistically different than EU9. With both EU12 and EU15, the regional trade bias remains positive but declines relative to EU9 (see Table 3); import expansion disappears with EU12 and becomes outright TD in EU15; export expansion, although positive, declines progressively in the two enlargement phases. The data seem to suggest that the EU peaked with a membership of ten. One way to interpret this result is that the two enlargements, one from 10 to 12 and the other from 12 to 15 , have raised the marginal cost for the EU to remain open to the outside world. The higher costs reflect a larger and more heterogeneous membership, stronger political coalitions against a liberal trade environment, and a unanimity decision rule. Higher marginal costs of maintaining an open environment combined with declining marginal benefits from expanding trade imply a smaller trade club (Fratianni and Pattison 2001). Clearly, this analysis omits other objectives underlying the expansion of the EU.

NAFTA can also be judged a building bloc, comparable to the EU but weaker than ASEAN. NAFTA2 created no regional trade bias but expanded imports from the rest of the world. NAFTA3 has a strong positive regional trade bias and import expansion but diverts exports from the rest of the world. Overall, TC exceeds TD and this RTA makes a contribution to global free trade (see Table 3).

CARICOM is a classic case of an expanding RTA with a positive regional trade bias achieved at the expense of trade with the outside world. Positive internal biases are present in CARICOM11, CARICOM12, and CARICOM13; they disappear in CARICOM14. Export TD appears consistently through all the expansion phases, whereas import expansion is marginally 
significant in three out of the four bloc sizes. Clearly, CARICOM14 is a stumbling bloc and a worse outcome for global free trade than when it was smaller (Table 3).

In sum, the four expanding RTAs have done better for global free trade than the seven static RTAs. ASEAN is the champion of building blocs; the EU and NAFTA have, on balance, contributed to the expansion of world trade; and CARICOM, in its present size, is a stumbling bloc. For ASEAN, the EU, and CARICOM regional trade bias has declined with size (see Table $3)$.

[Insert Table 3 here]

\section{Conclusions}

The main conclusion of this paper is that RTAs have produced a mixed record with respect to the important issue of whether they enhance or hamper freer trade in the world. Of the eleven RTAs considered in this paper, seven have kept a constant membership and four have enlarged at least once during our sample period 1980-2003. In the first group, only ANDEAN and SPARTECA are building blocs; the remaining five have diverted trade against outside countries with little or no trade creation inside the RTA. The four expanding RTAs have a much better record as building blocs, with ASEAN being the undisputed champion. The smaller EUs have also behaved like ASEAN, but the larger EU15 has diverted imports against the outside world. On balance, the EU has made a positive contribution to the expansion of world trade. A similar assessment holds for NAFTA. The smaller NAFTA showed no evidence of trade diversion against the rest of the world, although it did not expand trade between members. The enlarged NAFTA has produced large regional trade bias but in part at the expense of diverting exports 
against the outside world. CARICOM, of the four expanding RTAs, has the weakest record as a building bloc. The current size of CARICOM is clearly a stumbling bloc.

The evidence presented in the paper has some bearing on the optimal size of the RTA. Judged exclusively on the ability to create trade within the bloc, three out of the four expanding RTAs -ASEAN, the EU and CARICOM- have already peaked. But regional trade bias is only part of the story. ASEAN has remained a very open club towards the rest of the world through all its enlargement phases. Its history augurs well that future increase in size may not turn this RTA inward. The other three RTAs, on the other hand, have diverted trade against the rest of the world to different degrees. The EU and NAFTA divert trade in the last round of expansion and CARICOM have diverted trade consistently through all expansion phases. While it is difficult to predict what future enlargements may bring, we should keep in mind that as size increases heterogeneity of membership rises as well, and with it the cost of achieving and maintaining an open trade environment, especially if decision rules are based on unanimity. The upshot is that expanding sizes, within the intermediate range, may not only reduce regional trade bias but also external openness.

Our study has focused solely on the relationship between RTA size and trade expansion. To the extent that countries form new RTAs or join existing ones for other reasons -such as security or political issues--- we would not expect a predictable relationship between size and openness. Indeed, political economy considerations complicate matters. For example, Krishna (1998) suggests that import trade-diverting RTAs may be more politically acceptable than tradecreating RTAs because the former do not hurt domestic industry, whereas the latter do by replacing domestic production with production located in the members' countries. 


\section{References}

Anderson, J.E. (1979). A theoretical foundation for the gravity equation, American Economic Review, 69, 106-115.

Anderson, J.E. and van Wincoop, E. (2003). Gravity with gravitas: a solution to the border Problem, American Economic Review, 93, 170-192.

Andriamananjara, S. (1999). On the size and number of regional integration arrangements: a political economy model, World Bank Policy Research Working Paper No.2117.

Baldwin, R. and Taglioni, D. (2006). Gravity for dummies and dummies for gravity equations, NBER Working Paper Series No.12516.

Bayoumi, T. and Eichengreen, B. (1997). Is regionalism simply a diversion: evidence from the evolution of the EC and EFTA, In T. Ito and A. Krueger (eds.), Regionalism versus Multilateral Trade Arrangements, Chicago, The University of Chicago Press, pp.141-168.

Bergstrand, J.H. (1985). The gravity equation in international trade: some microeconomic foundations and empirical evidence, Review of Economics and Statistics, 67(3), 474-481.

Bergstrand, J.H. (1989). The generalized gravity equation, monopolistic competition, and the factorproportions theory in international trade, Review of Economics and Statistics 71(1), 143-153.

Bhagwati, J. (1991). The world trading system at risk. Princeton, N.J.: Princeton University Press.

Bond, E.W. and Syropoulos, C. (1996). The size of trading blocs, market power and world welfare effects, Journal of International Economics, 40, 411-437.

Breusch, T. and Pagan, A. (1980) The LM test and its applications to model specification in econometrics, Review of Economic Studies, 47, 239-254.

Carrère, C. (2006). Revisiting the effects of regional trade agreements on trade flows with proper specification of the gravity model, European Economics Review, 50, 223-247.

Crawford, J. and Fiorentino, R. (2005). The changing landscape of regional trade agreements, WTO Discussion Paper No.8. (World Trade Organization, Geneva).

Deardorff, A.V. (1998). Determinants of bilateral trade: does gravity work in a Neoclassical world? In J.A. Frankel (ed.), The Regionalization of the World Economy. Chicago: University of Chicago Press (for NBER).

Feenstra, R.C. (2003). Advanced International Trade, Princeton University Press, Princeton, NJ.

Feenstra, R.C., Markusen. R. and Rose, A.K. (2001). Using the gravity equation to differentiate among alternative theories of trade, Canadian Journal of Economics 34(2): 430-447.

Frankel, J.A., Stein, E. and Wei, S-J. (1996). Regional trading arrangements: natural or supernatural? American Economic Review, 86(2), 52-56. 
Fratianni, M. and Pattison, J. (2001). International organisations in a world of regional trade agreements: lessons from club theory, World Economy, 24(3), 333-358.

Haveman, J. and Hummels, D. (2004). Alternative hypotheses and the volume of trade; the gravity equation and the extent of specialization, Canadian Journal of Economics, 37(1), 199-218.

Hausman, J. (1978). Specification tests in econometrics, Econometrica, 46, 1251-1271.

Helpman, E. (1987). Imperfect competition and international trade: evidence from fourteen industrial countries, Journal of the Japanese and International Economies, 1, 62-81.

Krishna, P. (1998). Regionalism and multilateralism: a political economy approach, Quarterly Journal of Economics, 113(1), 227-251.

Krugman, P. (1991). Is bilateralism bad?, In E. Helpman and A. Razin (eds.), International Trade and Trade Policy, MIT Press, Cambridge, MA, pp.9-23.

Leamer, E,E. and Levinsohn, J. (1995). International trade theory: the evidence. In G.M. Grossman and K. Rogoff (eds.), Handbook of International Economics. Amsterdam: Elsevier.

Panagariya, A. (2000). Preferential trade liberalization: the traditional theory and new developments, Journal of Economic Literature, 38, 287-331.

Persson, T. (2001). Currency unions and trade: how large is the treatment effect? Economic Policy, 33, 435-448.

Pomfret, R. (2006). Regional trade agreements, In M. Fratianni (ed.), Regional Economic Integration, Elsevier, Amsterdam, pp.39-54.

Rose, A.K. (2000). One money, one market: The effects of common currency on trade, Economic Policy, 30, 9-45.

Rose, A.K. (2005). Which international institutions promote international trade? Review of International Economics, 13, 682-698.

Rose, A.K. and van Wincoop, E. (2001). National money as a barrier to international trade: the real case for currency union, American Economic Review, 91(2), 386-390.

Soloaga, I. and Winters, A. (2001). Regionalism in the nineties: what effect on trade? North American Journal of Economics and Finance, 12, 1-29..

Viner, J. (1950). The Customs Union Issue, Carnegie Endowment for International Peace, NY.

Yi, S-S (1996). Endogenous formation of customs unions under imperfect competition: open regionalism is good, Journal of International Economics, 41(1-2), 153-177. 
Table 1 Descriptive statistics of RTA dummy variables

\begin{tabular}{|c|c|c|c|c|c|}
\hline Variable & Mean & $\begin{array}{l}\text { Standard } \\
\text { Deviation }\end{array}$ & Variable & Mean & $\begin{array}{l}\text { Standard } \\
\text { Deviation }\end{array}$ \\
\hline ANDEAN: Same-RTA & 0.0015 & 0.0385 & CARICOM11: Same-RTA & 0.0005 & 0.0213 \\
\hline Export & 0.0266 & 0.1609 & Export & 0.0036 & 0.0597 \\
\hline Import & 0.0256 & 0.1578 & Import & 0.0041 & 0.0641 \\
\hline ANZCERTA: Same-RTA & 0.0002 & 0.0140 & CARICOM12: Same-RTA & 0.0018 & 0.0421 \\
\hline Export & 0.0224 & 0.1479 & Export & 0.0142 & 0.1182 \\
\hline Import & 0.0187 & 0.1354 & Import & 0.0178 & 0.1321 \\
\hline CACM: Same-RTA & 0.0012 & 0.0347 & CARICOM13: Same-RTA & 0.0005 & 0.0221 \\
\hline Export & 0.0186 & 0.1350 & Export & 0.0038 & 0.0614 \\
\hline Import & 0.0180 & 0.1329 & Import & 0.0050 & 0.0703 \\
\hline MERCOSUR: Same-RTA & 0.0007 & 0.0258 & CARICOM14: Same-RTA & 0.0012 & 0.0350 \\
\hline Export & 0.0202 & 0.1407 & Export & 0.0095 & 0.0971 \\
\hline Import & 0.0172 & 0.1300 & Import & 0.0125 & 0.1111 \\
\hline PATCRA: Same-RTA & 0.0002 & 0.0149 & NAFTA2: Same-RTA & 0.0000 & 0.0068 \\
\hline Export & 0.0174 & 0.1308 & Export & 0.0058 & 0.0763 \\
\hline Import & 0.0158 & 0.1247 & Import & 0.0057 & 0.0752 \\
\hline SPARTECA: Same-RTA & 0.0026 & 0.0508 & NAFTA3: Same-RTA & 0.0003 & 0.0167 \\
\hline Export & 0.0335 & 0.1799 & Export & 0.0162 & 0.1263 \\
\hline Import & 0.0321 & 0.1763 & Import & 0.0160 & 0.1255 \\
\hline USIS: Same-RTA & 0.0002 & 0.0129 & EU9: Same-RTA & 0.0002 & 0.0140 \\
\hline Export & 0.0182 & 0.1336 & Export & 0.0039 & 0.0621 \\
\hline Import & 0.0168 & 0.1284 & Import & 0.0037 & 0.0604 \\
\hline ASEAN6: Same-RTA & 0.0014 & 0.0373 & EU10: Same-RTA & 0.0013 & 0.0360 \\
\hline Export & 0.0333 & 0.1794 & Export & 0.0217 & 0.1455 \\
\hline Import & 0.0285 & 0.1665 & Import & 0.0208 & 0.1428 \\
\hline ASEAN7: Same-RTA & 0.0002 & 0.0136 & EU12: Same-RTA & 0.0038 & 0.0612 \\
\hline Export & 0.0049 & 0.0700 & Export & 0.0488 & 0.2155 \\
\hline Import & 0.0046 & 0.0673 & Import & 0.0467 & 0.2109 \\
\hline ASEAN9: Same-RTA & 0.0003 & 0.0175 & EU15: Same-RTA & 0.0074 & 0.0854 \\
\hline Export & 0.0058 & 0.0757 & Export & 0.0664 & 0.2491 \\
\hline Import & 0.0050 & 0.0705 & Import & 0.0621 & 0.2414 \\
\hline ASEAN10: Same-RTA & 0.0010 & 0.0322 & & & \\
\hline Export & 0.0179 & 0.1327 & & & \\
\hline Import & 0.0140 & 0.1176 & & & \\
\hline
\end{tabular}

Notes: See text for the descriptive statistics of other variables. 
Table 2 Estimates of the impact of RTAs on bilateral imports, 1980-2003

\begin{tabular}{|c|c|c|}
\hline & $\begin{array}{l}\text { Bilateral Country Pair } \\
\& \text { Year Fixed Effects }\end{array}$ & $\begin{array}{r}\text { Bilateral Country Pair Random } \\
\text { \& Year Fixed Effects }\end{array}$ \\
\hline Intercept & -40.1091 & -22.2509 \\
\hline Log of nominal GDP & 1.0211 & 0.8160 \\
\hline Log of nominal per capita GDP & -0.4450 & 0.0280 \\
\hline Log of distance & NA & -1.1406 \\
\hline Common border & NA & 0.5081 \\
\hline Common language & NA & 0.3904 \\
\hline Common colonizer & NA & 0.3566 \\
\hline Colonial relationship & NA & 1.7811 \\
\hline Common currency & $0.0780^{* *}$ & $0.0869^{* *}$ \\
\hline ANDEAN: Same-RTA & 0.6649 & 0.7923 \\
\hline Export & $0.0327^{* *}$ & $-0.0254^{* *}$ \\
\hline Import & $0.0476^{* *}$ & $-0.0881^{*}$ \\
\hline ANZCERTA: Same-RTA & $0.0176^{* *}$ & $-0.2229^{* *}$ \\
\hline Export & $0.0054^{* *}$ & $-0.0522^{\star *}$ \\
\hline Import & $-0.0175^{* *}$ & -0.2158 \\
\hline CACM: Same-RTA & $-0.2685^{\star}$ & $-0.0752^{* *}$ \\
\hline Export & -0.1911 & -0.2398 \\
\hline Import & 0.2255 & 0.1570 \\
\hline MERCOSUR: Same-RTA & $0.0190^{* *}$ & $0.0156^{\text {** }}$ \\
\hline Export & -0.2321 & -0.2032 \\
\hline Import & 0.3762 & 0.2093 \\
\hline PATCRA: Same-RTA & NA & $0.6362^{* *}$ \\
\hline Export & NA & $0.1106^{* *}$ \\
\hline Import & NA & $-0.2557^{\star}$ \\
\hline SPARTECA: Same-RTA & $-0.1326^{\star *}$ & 1.8082 \\
\hline Export & $-0.1192^{* *}$ & 0.3505 \\
\hline Import & $-0.1048^{* *}$ & 0.3087 \\
\hline USIS: Same-RTA & $0.0930^{* *}$ & 0.2407 \\
\hline Export & -0.1457 & $-0.1121^{*}$ \\
\hline Import & -0.2144 & -0.2347 \\
\hline ASEAN6: Same-RTA & 1.4035 & 1.7463 \\
\hline Export & 0.9585 & 0.4900 \\
\hline Import & 0.4486 & 0.8826 \\
\hline ASEAN7: Same-RTA & 1.7090 & 1.8627 \\
\hline Export & 1.3207 & 1.1767 \\
\hline Import & 0.8388 & 0.7903 \\
\hline ASEAN9: Same-RTA & 1.7132 & 1.9402 \\
\hline Export & 1.4432 & 1.3621 \\
\hline Import & 0.4824 & 0.4812 \\
\hline ASEAN10: Same-RTA & 0.9970 & 1.2012 \\
\hline Export & 1.3112 & 1.2126 \\
\hline Import & $0.1997^{\star}$ & 0.1930 \\
\hline CARICOM11: Same-RTA & $-0.1733^{\star \star}$ & 1.0683 \\
\hline Export & -0.4268 & -0.2496 \\
\hline Import & $-0.1077^{\star *}$ & $0.1505^{*}$ \\
\hline CARICOM12: Same-RTA & $-0.2919^{\star *}$ & 0.8647 \\
\hline
\end{tabular}




\begin{tabular}{|c|c|c|}
\hline Export & -0.5506 & -0.3677 \\
\hline Import & $-0.0742^{* *}$ & 0.1578 \\
\hline CARICOM13: Same-RTA & $-0.0997^{\star \star}$ & 0.9548 \\
\hline Export & -0.6843 & -0.5619 \\
\hline Import & $-0.0427^{\star \star}$ & $0.1046^{*}$ \\
\hline CARICOM14: Same-RTA & -0.7832 & $0.1045^{* \star}$ \\
\hline Export & -0.4699 & -0.3530 \\
\hline Import & $-0.0324^{\star *}$ & $0.0839^{*}$ \\
\hline NAFTA2: Same-RTA & $0.3327^{\star \star}$ & $0.3757^{\text {*t }}$ \\
\hline Export & $-0.0470^{\star *}$ & $0.0061^{\star *}$ \\
\hline Import & 0.1673 & 0.1749 \\
\hline NAFTA3: Same-RTA & 0.6825 & 0.7044 \\
\hline Export & -0.2228 & -0.1792 \\
\hline Import & 0.2639 & 0.2471 \\
\hline EU9: Same-RTA & $0.0940^{* *}$ & $0.4591^{*}$ \\
\hline Export & $-0.0333^{* *}$ & 0.2974 \\
\hline Import & 0.2103 & 0.4033 \\
\hline EU10: Same-RTA & 0.3404 & 0.7781 \\
\hline Export & $0.0574^{*}$ & 0.4221 \\
\hline Import & 0.1143 & 0.3411 \\
\hline EU12: Same-RTA & 0.3394 & 0.4998 \\
\hline Export & $-0.0159^{\star *}$ & 0.2413 \\
\hline Import & $-0.0792^{*}$ & $0.0422^{* *}$ \\
\hline EU15: Same-RTA & 0.2848 & 0.3516 \\
\hline Export & -0.1804 & $0.0468^{*}$ \\
\hline Import & -0.1636 & -0.0720 \\
\hline F-Test for Fixed Effects & \multicolumn{2}{|l|}{$\begin{array}{r}\text { Bilateral Country Pair Fixed Effects } \\
F(15653,199760)=15.24\end{array}$} \\
\hline Breusch and Pagan LM Test for & & $x^{2}=3.7 e+05$ \\
\hline Random Effects & & $\begin{array}{r}P>\chi^{2}=0.0 \\
\text { (Do not reiect Random Fffects) }\end{array}$ \\
\hline Hausman Test for Model & & $x^{2}=0.00$ \\
\hline Selection & & $P>\chi^{2}=1.00$ \\
\hline & & $\begin{array}{l}\text { (Fixed effects model is not better than } \\
\text { random effects model) }\end{array}$ \\
\hline Obs. & 215,000 & 215,000 \\
\hline $\mathrm{R}^{2}$ & 0.8299 & 0.8265 \\
\hline
\end{tabular}

Notes: All coefficients are significant at $1 \%$ level otherwise noticed. ${ }^{*}$ indicates significant at $10 \%$ level; ${ }^{* *}$ indicates not significant at $10 \%$ level. 
Table 3 Trade creation and trade diversion effects of RTAs based on random effects model

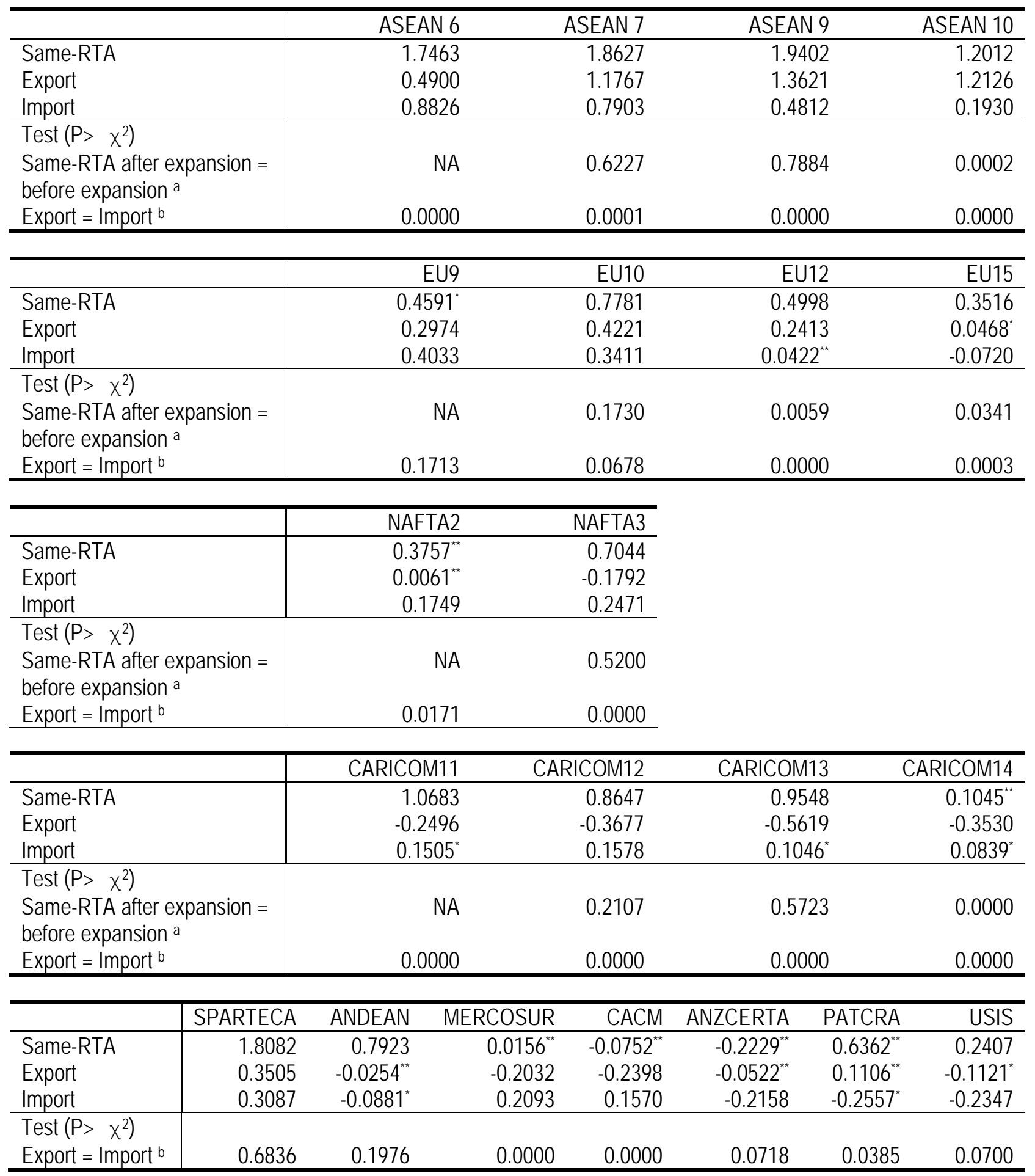

Notes:

${ }^{\mathrm{a}}$ Test for equality of regional trade bias coefficients before and after expansion of RTA. P-values indicate probabilities of the chi-square that the coefficients are different from each other.

${ }^{b}$ Test for equality of coefficients of export and import trade diversion. Rejection means that country's trade orientation differs between exports and imports. 


\section{Appendix 1 Data description}

\begin{tabular}{|c|c|c|c|}
\hline Variables & Descriptions & Data Sources & Units \\
\hline Bilateral Imports & Log of nominal bilateral imports & World Trade Analyzera & $\begin{array}{l}\text { Log of } 1000 \text { US } \\
\text { dollar }\end{array}$ \\
\hline Log of Nominal GDP & Log of the product of nominal GDPs. & $\begin{array}{l}\text { World Development } \\
\text { Indicatorb }\end{array}$ & Log of dollar \\
\hline $\begin{array}{l}\text { Log of nominal per } \\
\text { capita GDP }\end{array}$ & Log of the product of nominal per capita GDPs. & $\begin{array}{l}\text { World Development } \\
\text { Indicator }\end{array}$ & Log of dollar \\
\hline Log of Distance & Log of distance between trading partners & World Factbookc & Log of mile \\
\hline Common Border & $\begin{array}{l}\text { If two countries share a common border, } \\
\text { Common Border }=1 \text {, otherwise } 0 \text {. }\end{array}$ & World Factbookc & $\begin{array}{l}\text { Dummy } \\
\text { variable. }\end{array}$ \\
\hline Common language & $\begin{array}{l}\text { If two countries share same main language, } \\
\text { Common language }=1, \text { otherwise } 0 \text {. }\end{array}$ & World Factbook ${ }^{c}$ & $\begin{array}{l}\text { Dummy } \\
\text { variable. }\end{array}$ \\
\hline Common Colonizer & $\begin{array}{l}\text { If two countries had same colonizer, Common } \\
\text { Colonizer }=1 \text {. otherwise } 0 \text {. }\end{array}$ & World Factbook ${ }^{c}$ & $\begin{array}{l}\text { Dummy } \\
\text { variable. }\end{array}$ \\
\hline Colonial & If two countries were involved in a colonial & World Factbookc & Dummy \\
\hline Relationship & $\begin{array}{l}\text { relationship with each other, Colonial } \\
\text { Relationship }=1 \text {, otherwise } 0 \text {. }\end{array}$ & & variable. \\
\hline Common Currency & $\begin{array}{l}\text { If two countries share the same currency or a } \\
\text { unit exchange rate, Common Currency }=1 \text {, } \\
\text { otherwise } 0 \text {. }\end{array}$ & IMFe & $\begin{array}{l}\text { Dummy } \\
\text { variable. }\end{array}$ \\
\hline $\begin{array}{l}\text { Same-RTA } \\
\text { (11 RTAs) }\end{array}$ & $\begin{array}{l}\text { If two countries belong to the same RTA in the } \\
\text { year of observation, Same-RTA }=1 \text {, otherwise } \\
0 \text {; see Appendix } 3 \text { for RTA list. }\end{array}$ & WTOd & $\begin{array}{l}\text { Dummy } \\
\text { variable. }\end{array}$ \\
\hline Ex-RTA & $\begin{array}{l}\text { If exporting country belongs to a RTA and } \\
\text { importing does not, Ex-RTA = } 1 \text {, otherwise } 0 .\end{array}$ & WTOd & $\begin{array}{l}\text { Dummy } \\
\text { variable. }\end{array}$ \\
\hline Im-RTA & $\begin{array}{l}\text { If importing country belongs to a RTA and } \\
\text { exporting country does not, Im-RTA }=1 \text {, } \\
\text { otherwise } 0 \text {. }\end{array}$ & WTOd & $\begin{array}{l}\text { Dummy } \\
\text { variable. }\end{array}$ \\
\hline
\end{tabular}

Notes:

a "World Trade Analyzer" (WTA) has been assembled and managed by Statistics Canada. Information of the data is available at http://www.statcan.ca/english/ads/trade/world.htm

b The source for nominal GDP is World Bank's "World Development Indicators". When data are unavailable from World Bank, missing observations are filled from the "Penn World Table" and IMF's "International Financial Statistics".

c "World Factbook", CIA; http://www.cia.gov/coa/publication/factbook

${ }^{\mathrm{d}}$ The data available at http://www.wto.org/english/tratop_e/region_e.htm

e The basic source for currency unions is the IMF's "Schedule of Par Values" and issues of the IMF's "Annual Report on Exchange Rate Arrangements and Exchange Restrictions". Data are supplemented by the yearly "Statesman's Year Book". 


\section{Appendix 2 Country list}

\begin{tabular}{|c|c|c|c|}
\hline ALBANIA & DOMINICAN RP & KUWAIT & RWANDA \\
\hline ALGERIA & ECUADOR & LAOS P.DEM.R & SAUDI ARABIA \\
\hline ANGOLA & EGYPT & LIBERIA & SENEGAL \\
\hline ARGENTINA & EL SALVADOR & LIBYA & SERVIA \& MONTE. \\
\hline AUSTRALIA & EQ. GUINEA & MADAGASCAR & SEYCHELLES \\
\hline AUSTRIA & ETHIOPIA & MALAWI & SIERRA LEONE \\
\hline BAHAMAS & $\mathrm{FIJI}$ & MALAYSIA & SINGAPORE \\
\hline BAHRAIN & FINLAND & MALDIVES & SLOVAK RP \\
\hline BANGLADESH & FRANCE & MALI & SOLOMON ISLDS \\
\hline BARBADOS & GABON & MALTA & SOMALIA \\
\hline BELGIUM-LUX. & GAMBIA & MAURITANIA & SOUTH AFRICA \\
\hline BELIZE & GERMANY & MAURITIUS & SPAIN \\
\hline BENIN & GHANA & MEXICO & SRI LANKA \\
\hline BERMUDA & GREECE & MONGOLIA & ST KITTS NEV \\
\hline BHUTAN & GUATEMALA & MOROCCO & SUDAN \\
\hline BOLIVIA & GUINEA & MOZAMBIQUE & SURINAME \\
\hline BRAZIL & GUINEA-BISSAU & NEPAL & SWEDEN \\
\hline BULGARIA & GUYANA & NETHERLANDS & SWITZERLAND \\
\hline BURKINA FASO & HAITI & NEW ZEALAND & SYRN ARAB RP \\
\hline BURUNDI & HONDURAS & NICARAGUA & TANZANIA \\
\hline CAMBODIA & HONG KONG & NIGER & THAILAND \\
\hline CAMEROON & HUNGARY & NIGERIA & TOGO \\
\hline CANADA & ICELAND & NORWAY & TRINIDAD TBG \\
\hline CENTRAL AFR. REP. & INDIA & OMAN & TUNISIA \\
\hline CHAD & INDONESIA & PAKISTAN & TURKEY \\
\hline CHILE & IRAN & PANAMA & UGANDA \\
\hline CHINA & IRAQ & PAPUA N.GUINEA & UK \\
\hline COLOMBIA & IRELAND & PARAGUAY & UNTD ARAB EM \\
\hline COMOROS & ISRAEL & PERU & URUGUAY \\
\hline CONGO & ITALY & PHILIPPINES & USA \\
\hline CONGO DEM. REP. & JAMAICA & POLAND & VENEZUELA \\
\hline COSTA RICA & JAPAN & PORTUGAL & VIETNAM \\
\hline COTE D'IVOIRE & JORDAN & QATAR & YEMEN \\
\hline CYPRUS & KENYA & REUNION & ZAMBIA \\
\hline DENMARK & KIRIBATI & ROMANIA & ZIMBABWE \\
\hline DJIBOUTI & KOREA RP & RUSSIA & \\
\hline
\end{tabular}

Note. RUSSIA includes former USSR before 1989, SLOVAKIA includes former Czechoslovakia before 1993, and SERVIA AND MONTENEGRO includes former Yugoslavia before 1992. 


\section{Appendix 3 Eleven RTAs in the sample}

\begin{tabular}{|c|c|c|}
\hline Name & Country & Year of entry \\
\hline European Union & $\begin{array}{l}\text { Belgium } \\
\text { France } \\
\text { Germany } \\
\text { Italy } \\
\text { Luxembourg } \\
\text { Netherlands } \\
\text { Denmark } \\
\text { Ireland } \\
\text { United Kingdom } \\
\text { Greece } \\
\text { Portugal } \\
\text { Spain } \\
\text { Austria } \\
\text { Sweden } \\
\text { Finland }\end{array}$ & $\begin{array}{l}58 \\
58 \\
58 \\
58 \\
58 \\
58 \\
73.1 .1 \\
73.1 .1 \\
73.1 .1 \\
81.1 .1 \\
86.1 .1 \\
86.1 .1 \\
95.1 .1 \\
95.1 .1 . \\
95.1 .1 . \\
\end{array}$ \\
\hline US-IS & $\begin{array}{l}\text { US } \\
\text { Israel }\end{array}$ & $\begin{array}{l}\text { 85.8.19. } \\
\text { 85.8.19. }\end{array}$ \\
\hline NAFTA & $\begin{array}{l}\text { US } \\
\text { Mexico } \\
\text { Canada } \\
\end{array}$ & $\begin{array}{l}\text { 89.1.1. } \\
94.1 .1 . \\
89.1 .1 . \\
\end{array}$ \\
\hline $\begin{array}{l}\text { CARICOM } \\
\text { (Montserrat) }\end{array}$ & $\begin{array}{l}\text { Ant.\&Barbuda } \\
\text { Bahamas } \\
\text { Barbados } \\
\text { Belize } \\
\text { Dominica } \\
\text { Grenada } \\
\text { Guyana } \\
\text { Haiti } \\
\text { Jamaica } \\
\text { St.Kitts \& Nevis } \\
\text { St.Lucia } \\
\text { St.Vin. \& Grana. } \\
\text { Surinam } \\
\text { Trinidad Tobago } \\
\end{array}$ & $\begin{array}{l}73.8 .1 . \\
83.7 .4 . \\
73.8 .1 . \\
73.8 .1 . \\
73.8 .1 . \\
73.8 .1 . \\
73.8 .1 . \\
98.7 .4 . \\
73.8 .1 . \\
73.8 .1 . \\
73.8 .1 . \\
73.8 .1 . \\
95.7 .4 . \\
73.8 .1 .\end{array}$ \\
\hline PATCRA & $\begin{array}{l}\text { Australia } \\
\text { Papua N. Guinea }\end{array}$ & $\begin{array}{l}\text { 77.2.1. } \\
77.2 .1 .\end{array}$ \\
\hline ANZCERTA & $\begin{array}{l}\text { Australia } \\
\text { New Zealand }\end{array}$ & $\begin{array}{l}83.1 .1 \\
83.1 .1\end{array}$ \\
\hline CACM & $\begin{array}{l}\text { Costa Rica } \\
\text { El Salvador } \\
\text { Guatemala } \\
\text { Honduras } \\
\text { Nicaragua }\end{array}$ & $\begin{array}{l}63 \sim 69,91 \sim \\
61 \cdot 10.12 \sim 69,91 \sim \\
61 \cdot 10.12 \sim 69,91 \sim \\
61.10 .12 \sim 69,91 \sim \\
61 \cdot 10.12 \sim 69,91 \sim\end{array}$ \\
\hline MERCOSUR & $\begin{array}{l}\text { Argentina } \\
\text { Brazil } \\
\text { Paraguay } \\
\text { Uruguay }\end{array}$ & $\begin{array}{l}91 \\
91 \\
91 \\
91 \\
\end{array}$ \\
\hline
\end{tabular}




\begin{tabular}{l|l|l}
\hline ASEAN & Philippines & 67.8 .8$. \\
(Brunei) & Indonesia & 67.8 .8$. \\
& Malaysia & 67.8 .8$. \\
& Singapore & 67.8 .8$. \\
& Thailand & 67.8 .8$. \\
& Vietnam & 95.7 .28$. \\
& Peo.Dem.Rep. Laos & 97.7 .23$. \\
& Burma & 97.7 .23$. \\
& Cambodia & 99.4 .30$. \\
\hline SPARTECA & Ausrailia & 81.1 .1$. \\
Nauru & New Zealand & 81.1 .1$. \\
Niue & Fiji & 81.1 .1$. \\
Tuvalu) & Kiribati & 81.1 .1$. \\
& Papua N. Guinea & 81.1 .1$. \\
& Solomon Islands & 81.1 .1$. \\
& Tonga & 81.1 .1$. \\
\hline ANDEAN & Vanuatu & 81.1 .1$. \\
& Samoa & 81.1 .1$. \\
\hline & Bolivia & 88.5 .24$. \\
& Colombia & 88.5 .24$. \\
& Ecuador & 88.5 .24$. \\
& Peru & 88.5 .24$. \\
& Venezuela & 88.5 .24$. \\
\hline
\end{tabular}

Source: Official website of World Trade Organization (WTO) and individual RTAs.

Note: Counties shown in parentheses below RTA names are member countries for which we do not have bilateral import data. CACM was suspended in 1970-1990. 